\title{
Media coverage of the Covid-19 crisis: recommendations and proposals for self-regulation
}

\author{
Marcel Mauri-Ríos; Xavier Ramon-Vegas; Ruth Rodríguez-Martínez
}

Nota: Este artículo se puede leer en español en:

https://profesionaldelainformacion.com/contenidos/2020/nov/mauri-ramon-rodriguez_es.pdf

How to cite this article:

Mauri-Ríos, Marcel; Ramon-Vegas, Xavier; Rodríguez-Martínez, Ruth (2020). “Media coverage of the Covid-19 crisis: recommendations and proposals for self-regulation". Profesional de la información, v. 29, n. 6, e290622. https://doi.org/10.3145/epi.2020.nov.22

Article received on 01-08-2020 Final acceptance: 10-08-2020

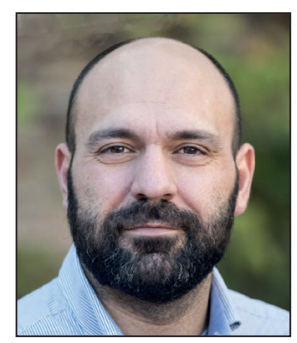

Marcel Mauri-Ríos $\square$ https://orcid.org/0000-0003-2615-8343

Universitat Pompeu Fabra

Departament de Comunicació

Roc Boronat, 138

08018 Barcelona, Spain

marcel.mauri@upf.edu

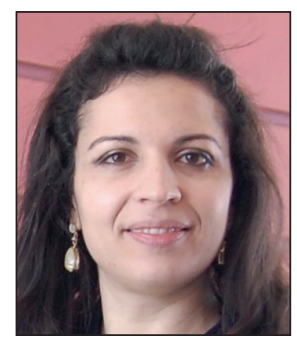

\section{Ruth Rodríguez-Martínez}

https://orcid.org/0000-0001-5633-6126

Universitat Pompeu Fabra

Departament de Comunicació

Roc Boronat, 138

08018 Barcelona, Spain

ruth.rodriguez@upf.edu

\begin{abstract}
This paper aims to present, analyze, and compare the main deontological recommendations published by various international institutions and organizations since the beginning of the Covid-19 crisis. A total of 10 codes were identified from the period between February and April 2020, during which the World Health Organization declared the Covid-19 outbreak a global pandemic. Additionally, three general and transnational model deontological texts published before the crisis have been included in this analysis. The methodology used in this paper includes a content analysis based on four categories corresponding to the fundamental pillars of most deontological codes: truth, freedom, responsibility, and justice. Furthermore, this paper determines the most common ethical guidelines and criteria presented in all the analyzed texts and, with the goal of helping information and journalistic professionals, these guidelines are used as a reference point to propose an outline of recommendations for the responsible coverage of the Covid-19 crisis.
\end{abstract}

\section{Keywords}

Ethics; Journalism; Accountability; Crisis; Covid-19; Coronavirus; Self-regulation; Truth; Responsibility; Justice; Freedom; Recommendations; Pandemics; Deontological codes; Deontology; Profession; State of the art; Review; Journalists.

\section{Funding}

This article is a result of the project "Instrumentos de rendición de cuentas ante la desinformación: impacto de las plataformas de fact-checking como herramientas de accountability y propuesta curricular" funded by the Spanish Ministry of Science and Innovation. Reference: PID2019-106367GB-I00/AEI/10.13039/501100011033 


\section{Introduction}

For more than a decade the media sector has suffered various crises that have spread to the vast majority of countries (Almiron, 2009; Alexander; Breese; Luengo, 2016). Although there are no aggregated data on the evolution of these crises in journalism on a global scale, studies from a diverse array of countries such as the United Kingdom (Sherwood; O'Donnell, 2018), Spain (Casero-Ripollés, 2010; Reig, 2015), and Australia (Ricketson et al., 2020) demonstrate their global impact.

Without having reestablished the economic stability and high employment rate of the previous decade, journalism faces a new global crisis in 2020 in the form of Covid-19, all the while trying to cope with an ever-changing journalistic context marked by job insecurity and a credibility crisis (Figueras-Maz; Mauri-Ríos; Alsius; Salgado-De-Dios, 2012; Hanitzsch; Van-Dalen; Steindl, 2018). Within this field, news consumption has increased markedly during the pandemic (Casero-Ripollés, 2020; Masip et al., 2020). As Casero-Ripollés (2020, p. 2) points out, information

"Is a valuable mechanism for guiding people, especially in highly complex situations such as the one generated by the Covid-19 pandemic".

In parallel, the dissemination of disinformation across multiple media platforms has become a key concern ever since the beginning of the pandemic (Pérez-Dasilva et al., 2020; Pulido et al., 2020; Salaverría et al., 2020). In February 2020, the World Health Organization declared the existence of an infodemic (WHO, 2020). Amongst the reliable and verified information surrounding Covid-19, there is a growing amount of hoaxes and inaccurate, distorted, or decontextualized information in relation to the origin, expansion, and lethality of the virus, along with disinformation about the management of the crisis by governments and international organizations, and the potential remedies and cures (Brennen et al., 2020; Sánchez-Duarte; Magallón-Rosa, 2020). Recent studies also evidence the frequent use of false images and illustrations to represent the virus (Andreu-Sánchez; Martín-Pascual, 2020) in the media, especially digital.

The uncertainty and difficulties posed by this crisis require journalists and the media to follow certain ethical parameters that guarantee professional excellence and quality of information (Maciá-Barber, 2020; Ramon-Vegas; Mauri-Ríos; Díaz-Campo, 2020) not only with the intention of adding value to their work, but also to provide those facing the challenges of the current situation with adequate informational responses (Christians; Nordenstreng, 2004).

Taking into account the fundamental role of self-regulation by the media, the objective of this article is to determine the guidelines that journalists and the media should follow when carrying out responsible and quality coverage of the Covid-19 crisis, based on codes of ethics considered as international benchmarks and specific recommendations published by international institutions and organizations since the beginning of the pandemic. These documents make up the basics of journalistic self-regulation, thus their analysis and comparison allow us to verify which guidelines of ethical conduct appear repeatedly in the codes or recommendations.

Without having reestablished the economic stability and high employment rate of the previous decade, journalism faces a new global crisis in 2020 in the form of Covid-19

\section{Self-regulation and ethical codes: state of the art}

There is a clear relationship between informational quality, professional ethics, and self-regulation, with the latter contributing to the implementation of responsible professional behaviors that produce ethical and quality information (González; Lecaros, 2020) and guarantee citizens' rights to this information. Thus, the concept of self-regulation is defined as journalists' and the media's ability to follow, of their own free will, the norms that represent universal ethical values (Wilkins; Christians, 2020). Self-regulation is understood as the professional conduct guidelines that position journalists between the minimum regulation imposed by law and the flexible ethical ideal (Aznar, 2005). In other words, it responds to the excessive regulatory ambition of political power without forgetting the typical journalistic responsibilities that allow journalists to correct any internal factors that could make them vulnerable to professional malpractice or external pressures (Evers, 2012; González; Lecaros, 2020; Real-Rodríguez, 2018).

Self-regulation is also one of the fundamental concepts of accountability, together with informative transparency and audience participation (Ramon-Vegas; Mauri-Ríos; Alcalá-Anguiano, 2016). Understood as the responsibility adopted by journalists and the media (not ordered by public or state agencies), accountability becomes a fundamental element in the present context (Bertrand, 2018). The need to combat commercialization and sensationalism in the media has contributed to the progressive incorporation of accountability into professional journalistic activity (Bardoel; D'Haenens, 2004).

Previous research shows how communication professionals wish to be accountable to the public (Alsius, 2010; Fengler et al., 2015) so that they can participate in the

"process by which media organizations may be expected or obliged to render an account of their activities to their constituents" (Pritchard, 2000, p. 2). 
In this way, accountability is a tool that helps the media to

"maintain their independence and credibility" (Maier, 2014, p. 1),

making it a key element within the field of journalism in times of crisis.

Accountability instruments, either created within the media or externally, allow journalism professionals to develop the following three dimensions (Ramon-Vegas; Mauri-Ríos; Alcalá-Anguiano, 2016; Fengler, 2019):

- self-regulation,

- participation, and

- information transparency.

The accountability instruments in question are specified within the deontological codes based on the ethical standards and recommendations drawn up by the media themselves or independent institutions that ensure the existence of responsible journalism and quality information (Fengler et al., 2014). These codes include the norms that contain the values and ethical principles recognized as the journalistic ideal to follow (Bertrand, 2018), and they establish a commitment between the media and audience. In this way, they become a social contract since journalists become aware of the behavioral and general expectations of them, and the user knows what to expect from the media (Christians; Nordenstreng, 2004). At the same time, deontological codes are a fundamental self-regulatory mechanism to guarantee the social right to receive information (Mauri-Ríos; Marcos-García; Zuberogoitia-Espilla, 2020).

Recent studies have mentioned more than 310 codes present in most countries (Duncan, 2019), and to a large extent, all of them refer to the four fundamental pillars as follows: the respect for informational truth, the guarantee of fair information, the promotion of social responsibility and solidarity of the media before human dignity, and the defense of freedom (Christians; Nordenstreng, 2004; Himelboim; Limor, 2008; Alsius, 2010; Bertrand, 2018). Other values commonly seen within this type of code include honesty, respect for privacy and human dignity, nonstigmatization of groups, and avoiding conflicts of interest (Cooper, 1990; Herrscher, 2002). Codes, or recommendations, become essential self-regulation tools in crisis situations (Duncan, 2019) since they offer highly useful ethical guidelines to information professionals (Auman; Stos; Burch, 2020; Mauri-Ríos; Marcos-García; Zuberogoitia-Espilla, 2020).

\section{Objectives and methodology}

While previous research has provided a comparative perspective on existing ethical codes in an international context, no research incorporating the ethical recommendations published to guarantee meticulous and quality coverage of the Covid-19 crisis has been carried out to date. The goals of the current research are thus as follows:

(a) to determine whether international ethical reference codes (from Unesco, the International Federation of Journalists, and the Council of Europe) (Aznar, 2005; Alsius, 2010) offer journalists and the media sufficient guidance during situations such as the Covid-19 pandemic;

(b) to identify, describe, analyze, and compare the ethical codes or professional deontological recommendations prepared by the media or independent organizations on how to ethically cover the crisis caused by the Covid-19 pandemic. These texts serve as a guide for journalists who wish to contribute useful, responsible information that encourages quality journalism;

(c) to detect the principles, norms, or recommendations that recurrently appear in the identified codes or texts from the media or independent organizations;

(d) to propose a set of ethical recommendations intended to serve as a guide for the media and journalists when covering pandemics and health crises.

To achieve these objectives, a systematic review of the main ethical codes (Aznar, 2005; Alsius, 2010) published by international organizations was carried out to identify the items or principles that could be applicable in a crisis situation (Table 1). This made it possible to, on the one hand, determine whether reference codes provide sufficient guidance during the current crisis and, on the other, identify the patterns that appear recurrently in the analyzed documents.

Table 1. Codes from independent international organizations

\begin{tabular}{|l|l|l|l|}
\hline \multicolumn{1}{|c|}{ Organization } & \multicolumn{1}{|c|}{ Code } & \multicolumn{1}{c|}{$\begin{array}{c}\text { Wubsite } \\
\text { date }\end{array}$} \\
\hline Unesco & $\begin{array}{l}\text { International Principles of Professional } \\
\text { Ethics in Journalism }\end{array}$ & $\begin{array}{l}\text { https://research.uta.fi/ethicnet/country/international- } \\
\text { principles-of-professional-ethics-in-journalism }\end{array}$ \\
\hline $\begin{array}{l}\text { International Federa- } \\
\text { tion of Journalists }\end{array}$ & World Charter of Ethics for Journalists & $\begin{array}{l}\text { https://www.if.org/es/quien/reglas-y-politica/carta-mundial- } \\
\text { de-etica-para-periodistas.html }\end{array}$ \\
\hline Council of Europe & Resolution 1003. Ethics of journalism & $\begin{array}{l}\text { https://assembly.coe.int/nw/XmI/XRef/Xref-XML2HTML-en. } \\
\text { asp?fileid=16414\&lang=en }\end{array}$ \\
\hline
\end{tabular}


Table 2. Codes from independent international organizations

\begin{tabular}{|c|c|c|c|}
\hline Organization & Code & Website & $\begin{array}{l}\text { Publication } \\
\text { date }\end{array}$ \\
\hline $\begin{array}{l}\text { 01. Asian American } \\
\text { Journalists Association }\end{array}$ & $\begin{array}{l}\text { AAJA calls on news organizations to exercise } \\
\text { care in coverage of the coronavirus outbreak }\end{array}$ & $\begin{array}{l}\text { https://www.aaja.org/guidance_on_coronavirus_ } \\
\text { coverage }\end{array}$ & $\begin{array}{l}13 \text { February } \\
2020\end{array}$ \\
\hline $\begin{array}{l}02 . \text { Scientific Ame- } \\
\text { rican }\end{array}$ & $\begin{array}{l}\text { How to report on the Covid-19 outbreak } \\
\text { responsibly }\end{array}$ & $\begin{array}{l}\text { https://blogs.scientificamerican.com/observations/how- } \\
\text { to-report-on-the-covid-19-outbreak-responsibly }\end{array}$ & $\begin{array}{l}23 \text { February } \\
2020\end{array}$ \\
\hline $\begin{array}{l}\text { 03. The Open Note- } \\
\text { book }\end{array}$ & $\begin{array}{l}\text { Tipsheet: covering the coronavirus } \\
\text { epidemic effectively without spreading } \\
\text { misinformation }\end{array}$ & $\begin{array}{l}\text { https://www.theopennotebook.com/2020/03/02/ } \\
\text { tipsheet-covering-the-coronavirus-epidemic-effectively- } \\
\text { without-spreading-misinformation }\end{array}$ & 2 March 2020 \\
\hline $\begin{array}{l}\text { 04. Poynter Institute } \\
\text { for the Study of Jour- } \\
\text { nalism }\end{array}$ & $\begin{array}{l}\text { How newsrooms can tone down their } \\
\text { coronavirus coverage while still reporting } \\
\text { responsibly }\end{array}$ & $\begin{array}{l}\text { https://www.poynter.org/reporting-editing/2020/how- } \\
\text { newsrooms-can-tone-down-their-coronavirus-coverage- } \\
\text { while-still-reporting-responsibly }\end{array}$ & 4 March 2020 \\
\hline $\begin{array}{l}\text { 05. Journalists' } \\
\text { Resource }\end{array}$ & $\begin{array}{l}\text { Covering Covid-19 and the coronavirus: } 5 \\
\text { tips from a Harvard epidemiology professor }\end{array}$ & $\begin{array}{l}\text { https://journalistsresource.org/studies/society/public- } \\
\text { health/covid-19-coronavirus-epidemiology }\end{array}$ & 6 March 2020 \\
\hline $\begin{array}{l}\text { 06. International Ne- } \\
\text { twork of Journalists }\end{array}$ & $\begin{array}{l}\text { Ten tips for journalists covering the new } \\
\text { coronavirus }\end{array}$ & $\begin{array}{l}\text { https://ijnet.org/es/story/diez-consejos-para-periodistas- } \\
\text { que-cubren-el-nuevo-coronavirus }\end{array}$ & 6 March 2020 \\
\hline 07. First Draft & $\begin{array}{l}\text { Coronavirus: Responsible reporting and } \\
\text { ethics }\end{array}$ & $\begin{array}{l}\text { https://firstdraftnews.org/long-form-article/coronavirus- } \\
\text { responsible-reporting-and-ethics }\end{array}$ & $\begin{array}{l}11 \text { March } \\
2020\end{array}$ \\
\hline $\begin{array}{l}\text { 08. Ethical Journalism } \\
\text { Network }\end{array}$ & $\begin{array}{l}\text { Media ethics, safety, and mental health: } \\
\text { reporting in the time of Covid-19 }\end{array}$ & $\begin{array}{l}\text { https://ethicaljournalismnetwork.org/media-ethics-safety- } \\
\text { and-mental-health-reporting-in-the-time-of-covid-19 }\end{array}$ & $\begin{array}{l}18 \text { March } \\
2020\end{array}$ \\
\hline $\begin{array}{l}\text { 09. Madrid Press } \\
\text { Association }\end{array}$ & $\begin{array}{l}\text { Recommendations for journalists covering } \\
\text { the pandemic }\end{array}$ & $\begin{array}{l}\text { https://www.apmadrid.es/recopilacion-de-recomendaciones- } \\
\text { para-periodistas-que-cubren-la-pandemia }\end{array}$ & $\begin{array}{l}30 \text { March } \\
2020\end{array}$ \\
\hline $\begin{array}{l}\text { 10. Pan American } \\
\text { Health Organization }\end{array}$ & $\begin{array}{l}\text { Covid-19. Tips for reporting. Guide for } \\
\text { journalists }\end{array}$ & $\begin{array}{l}\text { https://www.paho.org/es/documentos/covid-19- } \\
\text { consejos-para-informar-guia-para-periodistas }\end{array}$ & 8 April 2020 \\
\hline
\end{tabular}

Secondly, we proceeded to identify the ethical recommendations published with specific information on the coverage of Covid-19. To obtain a complete sample of these recommendations at an international level, we began with a sample that took into account the codes and recommendations of international institutions and self-regulatory bodies, as well as European, US, and Latin American platforms in the field of ethics (considered as such by the aforementioned bibliography, i.e., the Ethical Network or the European Journalism Observatory) to confirm whether they specifically mentioned any recommendations regarding Covid-19 coverage.

For this, a two-stage approach was adopted. Firstly, nonprobabilistic convenience sampling was carried out (Ruiz-Olabuénaga; Aristegui; Melgosa, 1998). The websites of these institutions, self-regulatory bodies, and reference platforms in journalistic ethics were consulted to identify whether they included any specific references to Covid-19. To achieve maximum completeness in the sample, a second sampling technique was used: snowball sampling (Goodman, 1961; Biernacki; Waldorf, 1981). This is mainly used in qualitative research (Brickman-Bhutta, 2012; Bryman, 2016) to identify elements to be incorporated into a sample that is very broad, dispersed, and difficult to group. The aforementioned websites and digital platforms served as a starting point to apply this strategy and find other media or institutions that had prepared recommendations on the informational treatment of Covid-19. Recommendations in English or Spanish language prepared by actors in the professional environment were progressively incorporated into the study, while discarding other materials that could have distorted the analysis (for
Table 3. Ethical principles examined following the proposal of Alsius (2010)

\begin{tabular}{|c|}
\hline 1. Principle of responsibility \\
\hline 1.1. Importance of life and the safety of people \\
\hline 1.1.1. Priority of humanitarian aid \\
\hline 1.1.2. Public safety and security \\
\hline 1.2. Privacy \\
\hline 1.2.1. Invasion of privacy \\
\hline 1.2.2. Child protection \\
\hline 1.2.3. The right to one's own image \\
\hline 1.2.4. Pain and suffering \\
\hline 1.3. Subjects of special social sensitivity \\
\hline 1.3.1 Bad taste \\
\hline 1.3.2. Alarmism \\
\hline 2. Principle of truth \\
\hline 2.1. Informative rigor \\
\hline 2.1.1. Accuracy and precision \\
\hline 2.1.2. Conjectures, speculation, and rumors \\
\hline 2.1.3. Choice, citation, and credibility of sources \\
\hline 2.1.4. Contextualization of information \\
\hline 2.2. Value neutrality \\
\hline 2.2.1. Separation of information and opinion \\
\hline 2.2.2. News selection and inclusion criteria \\
\hline 2.3. Discursive procedures \\
\hline 2.3.1. Sensationalism and spectacularization \\
\hline 3. Principle of justice \\
\hline 3.2. Treatment of disadvantaged social groups \\
\hline 3.2.1. Racism and xenophobia \\
\hline 4. Principle of freedom \\
\hline 4.1. External constraints and conflicts of interest \\
\hline 4.1.1. Control of political power \\
\hline 4.1.2. Dependencies and commercial interests \\
\hline
\end{tabular}


example, advice or guidelines on the usage of social networks that were not part of a decalogue were excluded). The sample selection (Table 2) was carried out between the months of February and April 2020 and identified ten recommendations and documents.

Thirdly, once the sample was selected, the texts found were described and analyzed. To carry out this content analysis (Bryman, 2016), various analysis categories were configured based on the thesaurus proposal of deontological principles, elaborated by Alsius (2010) (Table 3). This author classifies the deontological values present in most ethical codes into four categories:

- responsibility,

- truth,

- justice, and

- freedom.

For this research, this proposal was adapted considering the principles that, after the first systematized review of the main codes detailed in the methodology section, could be applicable to the current crisis situation caused by Covid-19.

\section{Results}

\subsection{Analysis of general codes}

General codes of ethics offer a broad vision of the ethical guidelines that journalists and the media should follow (Bertrand, 2018). There are various international or transnational codes, but the three most representative codes (Aznar, 2005; Alsius, 2010) are as follows:

- Unesco's International Principles of Professional Ethics for Journalism, approved in Paris in 1983, with a total of 10 articles;

- The World Charter of Ethics for Journalists from the International Federation of Journalists, approved at the $30^{\text {th }}$ IFJ World Congress in Tunis in 2019 and intended as a revision of the IFJ Declaration of the Principles on the Conduct of Journalists of 1954, or Declaration of Bordeaux, made up of 16 points;

- Resolution 1003 on journalistic ethics, approved by the Council of Europe in 1993, the longest document of the three, with a total of 38 articles.

Analysis of the three texts allows us to identify some important principles applicable to the current health crisis caused by Covid-19, as presented in Table 4. According to the proposed analysis categories of responsibility, truth, freedom, and justice, there are various criteria that can be related to these principles:

- The points within the analyzed texts that reference the principle of responsibility are respect for privacy and matters of special social sensitivity, placing special emphasis on respect for privacy and human dignity, as well as an appeal to social responsibility of informants and the defense of democratic values.

- Linked to the principle of truth, these three fundamental texts emphasize the need to adhere to the objective reality of facts and informative rigor to promote precision and accuracy in news production and avoid conjecture, speculation, and rumors. It also highlights the choice, citation, and credibility of the sources and the contextualization of the information, as well as the neutrality and the selection of the news and its inclusion criteria, and care regarding the discursive procedures used, as well as avoiding sensationalism or spectacularization.

- In relation to the principle of justice, the three selected texts indicate the need to reject information that encourages prejudice, racism, or xenophobia.

- Finally, the principle of freedom is evidenced by the need for informational work not to be influenced by external conditions and conflicts of interest, especially by political powers in any circumstances or contexts.

Table 4. Principles covered in each reference code

\begin{tabular}{|c|c|c|c|}
\hline Deontological principle & Unesco & IFJ & Council of Europe \\
\hline \multicolumn{4}{|c|}{ 1. Principle of responsibility } \\
\hline 1.2. Privacy & $\begin{array}{l}\text { Article } 6 . \text { Respect for priva- } \\
\text { cy and human dignity }\end{array}$ & $\begin{array}{l}\text { Article } 8 \text {. The journalist will respect } \\
\text { privacy. }\end{array}$ & $\begin{array}{l}\text { 23. The right of individuals to privacy } \\
\text { must be respected. }\end{array}$ \\
\hline $\begin{array}{l}\text { 1.3. Subjects of special } \\
\text { social sensitivity }\end{array}$ & $\begin{array}{l}\text { 3. The journalist's social } \\
\text { responsibility } \\
\text { 7. Respect for public } \\
\text { interest } \\
\text { 8. Respect for universal } \\
\text { values and diversity of } \\
\text { cultures. } \\
\text { 9. Elimination of war and } \\
\text { other great evils confron- } \\
\text { ting humanity }\end{array}$ & & $\begin{array}{l}\text { 34. No-one should remain neutral vis-à- } \\
\text { vis the defence of democratic values. }\end{array}$ \\
\hline
\end{tabular}




\begin{tabular}{|c|c|c|c|}
\hline Deontological principle & Unesco & IFJ & Council of Europe \\
\hline \multicolumn{4}{|l|}{ 2. Principle of truth } \\
\hline \multicolumn{4}{|l|}{ 2.1. Informative rigor } \\
\hline $\begin{array}{l}\text { 2.1.1. Accuracy and } \\
\text { precision } \\
\text { 2.1.2. Conjectures, specu- } \\
\text { lation, and rumors } \\
\text { 2.1.3. Choice, citation, } \\
\text { and credibility of sources } \\
\text { 2.1.4. Contextualization } \\
\text { of the information }\end{array}$ & $\begin{array}{l}\text { 1. Peoples' right to true } \\
\text { information } \\
\text { 2. The journalist's dedica- } \\
\text { tion to objective reality }\end{array}$ & $\begin{array}{l}\text { 1. Respect for the facts and for the right } \\
\text { of the public to truth is the first duty of } \\
\text { the journalist. } \\
\text { 4. The journalist shall use only fair } \\
\text { methods to obtain information, images, } \\
\text { documents and data. } \\
\text { 5. The notion of urgency or immediacy } \\
\text { in the dissemination of information } \\
\text { shall not take precedence over the } \\
\text { verification of facts, sources and/or the } \\
\text { offer of a reply. }\end{array}$ & $\begin{array}{l}\text { 4. News broadcasting should be based } \\
\text { on truthfulness. } \\
\text { 21. Therefore journalism should not alter } \\
\text { truthful, impartial information or honest } \\
\text { opinions, or exploit them for media pur- } \\
\text { poses, in an attempt to create or shape } \\
\text { public opinion. } \\
\text { 25. In the journalist's profession the end } \\
\text { does not justify the means; therefore } \\
\text { information must be obtained by legal } \\
\text { and ethical means. }\end{array}$ \\
\hline \multicolumn{4}{|l|}{ 2.2. Value neutrality } \\
\hline $\begin{array}{l}\text { 2.2.1. Separation of infor- } \\
\text { mation and opinion } \\
\text { 2.2.2. News selection and } \\
\text { inclusion criteria }\end{array}$ & & $\begin{array}{l}\text { 2. In pursuance of this duty, the journa- } \\
\text { list shall at all times defend the princi- } \\
\text { ples of freedom in the honest collection } \\
\text { and publication of news, and of the } \\
\text { right of fair comment and criticism. He/ } \\
\text { she will make sure to clearly distinguish } \\
\text { factual information from commentary } \\
\text { and criticism. }\end{array}$ & \\
\hline 2.3. Discursive procedures & & $\begin{array}{l}\text { 3. The journalist shall report only in } \\
\text { accordance with facts of which he/she } \\
\text { knows the origin. The journalist shall } \\
\text { not suppress essential information or } \\
\text { falsify any document. He/she will be ca- } \\
\text { reful to reproduce faithfully statements } \\
\text { and other material that non-public } \\
\text { persons publish in social media. }\end{array}$ & \\
\hline $\begin{array}{l}\text { 2.3.1. Sensationalism and } \\
\text { spectacularization }\end{array}$ & & & $\begin{array}{l}\text { 15. Neither publishers and proprietors } \\
\text { nor journalists should consider that they } \\
\text { own the news. News organisations must } \\
\text { treat information not as a commodity } \\
\text { but as a fundamental right of the citizen. } \\
\text { To that end, the media should exploit } \\
\text { neither the quality nor the substance } \\
\text { of the news or opinions for purposes of } \\
\text { boosting readership or audience figures } \\
\text { in order to increase advertising revenue. } \\
30 \text {. In journalism, controversial or } \\
\text { sensational items must not be confused } \\
\text { with subjects on which it is important to } \\
\text { provide information }\end{array}$ \\
\hline \multicolumn{4}{|l|}{ 3. Principle of justice } \\
\hline $\begin{array}{l}\text { 3.2.1. Racism and xe- } \\
\text { nophobia }\end{array}$ & & $\begin{array}{l}\text { 9. Journalists shall ensure that the } \\
\text { dissemination of information or opinion } \\
\text { does not contribute to hatred or preju- } \\
\text { dice and shall do their utmost to avoid } \\
\text { facilitating the spread of discrimination } \\
\text { on grounds such as geographical, social } \\
\text { or ethnic origin, race, gender, sexual } \\
\text { orientation, language, religion, disabili- } \\
\text { ty, political and other opinions. }\end{array}$ & \\
\hline \multicolumn{4}{|l|}{ 4. Principle of freedom } \\
\hline $\begin{array}{l}\text { 4.1. External constraints } \\
\text { and conflicts of interest }\end{array}$ & & $\begin{array}{l}\text { 11. The journalist shall refrain from } \\
\text { acting as an auxiliary of the police or } \\
\text { other security services. }\end{array}$ & \\
\hline $\begin{array}{l}\text { 4.1.1. Control of political } \\
\text { power } \\
\text { 4.1.2. Dependencies and } \\
\text { commercial interests }\end{array}$ & & $\begin{array}{l}\text { 14. The journalist will not undertake any } \\
\text { activity or engagement likely to put his/ } \\
\text { her independence in danger. He/she } \\
\text { will, however, respect the methods of } \\
\text { collection/dissemination of information } \\
\text { that he/she has freely accepted, such as } \\
\text { "off the record," anonymity, or embargo, } \\
\text { provided that these commitments are } \\
\text { clear and unquestionable. }\end{array}$ & $\begin{array}{l}\text { 8. ... without outside interference by ei- } \\
\text { ther the public authorities or the private } \\
\text { sector. } \\
\text { 29. In the relations which the journalist } \\
\text { must maintain in the course of his duties } \\
\text { with the public authorities or the various } \\
\text { economic sectors, care should be taken } \\
\text { to avoid any kind of connivance liable to } \\
\text { affect the independence and impartiality } \\
\text { of journalism. }\end{array}$ \\
\hline
\end{tabular}




\subsection{Specific recommendations applied to the Covid-19 crisis}

\subsubsection{Asian American Journalists Association (AAJA) https://www.aaja.org}

This nongovernmental organization brings together more than 1500 journalists from the USA and Asia and, on 13 February 2020, published a recommendation on the coverage of the health crisis, making it the first international organization to issue a text applied specifically to the Covid-19 crisis. The document, entitled "AAJA calls on news organizations to exercise care in coverage of the coronavirus outbreak," revolves around three basic points that appeal to the need for informational rigor and context to avoid speculation (principle of truth) and avoid terms such as "Wuhan virus," "China coronavirus," or any other mention of localities or populations to refer to the virus in order to avoid stigmatization (principle of justice).

\subsubsection{Scientific American \\ https://www.scientificamerican.com}

On 23 February 2020, one month after the first lockdown in Wuhan (China) but when no cases had yet been detected in the USA, the Scientific American, specialized in scientific and technological information, produced a document to provide journalists with deontological guidelines on the coverage of the crisis. The text is entitled "How to report on the Covid-19 outbreak responsibly" and consists of only three points. The first, within the principle of choice, citation, and credibility of sources, recommends turning to experts and scientists to offer complete coverage of the health crisis. The other two points are linked to the principle of responsibility and give priority to slow journalism that avoids rushing information and instead offers complete and contextualized information.

\subsubsection{The Open Notebook} https://www.theopennotebook.com

On 2 March 2020, this US organization, focused on helping journalists communicate scientific information clearly and accurately, published the document "Covering the coronavirus epidemic effectively without spreading misinformation." It is signed by Laura Helmuth, health and science editor of The Washington Post and former president of the National Association of Scientific Writers of the USA: https://www.nasw.org

The text has 13 points that focus mainly on four aspects. Within the principles of responsibility and the importance of life and the safety of people, it recommends that journalists indicate the uncertainty surrounding the coverage of the crisis to the audience. Regarding information rigor, the text points out the need to include the context in all the information, adequately define the concepts, and discredit false information. Regarding the choice of information sources, the text highlights the need to seek experts and avoid false balances in the choice of sources. Finally, linked to the principle of justice, it points out the importance of showing health personnel doing their work to avoid stigmatization.

\subsubsection{Poynter Institute https://www.poynter.org}

The Poynter Institute (St. Petersburg, FL, USA), a foundation and school for journalists that emphasizes deontology and fact-checking, published on 4 March 2020 the document "How newsrooms can tone down their coronavirus coverage while still reporting responsibly," signed by Al Tompkins, a senior professor at the institute, and consisting of six points relating to the principle of responsibility and truth. The first point indicates the need to choose the published material well to avoid alarmism. Within the principle of truth, it is recommended not to abuse adjectives, to avoid stigmatization or sensationalism and give context to the news, for example, prioritizing statistical data instead of anecdotes.

\subsubsection{Journalist's Resource https://journalistsresource.org}

On 6 March 2020, the Journalist's Resource, a US initiative that regularly publishes recommendations related to complex scientific issues, published the text "Covering Covid-19 and the coronavirus: 5 tips from a Harvard epidemiology professor." This document, comprising five basic points about the media

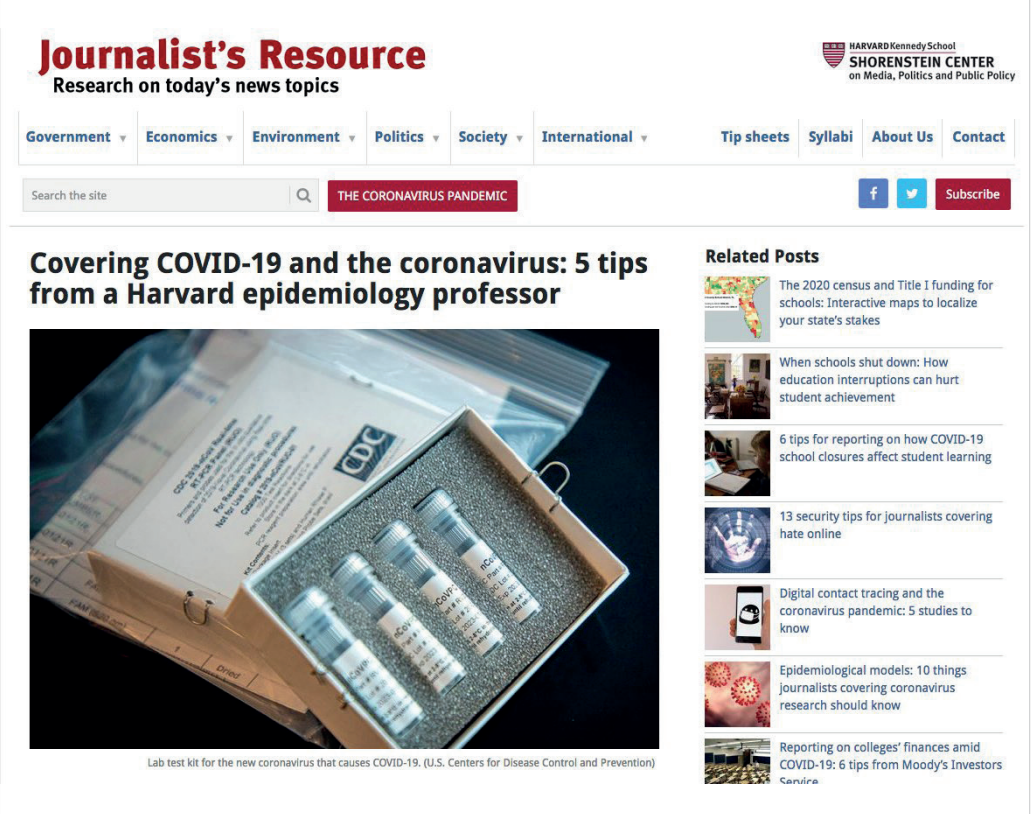

Figure 1. Recommendations published in the Journalist's Resource (Harvard Kennedy School's Shorenstein Center - Carnegie-Knight Initiative) 
coverage of the pandemic, was prepared by professor and journalist Denise-Marie Ordway. It delves into the principles that protect informational truth and focuses on two specific aspects: the choice and credibility of sources, with a recommendation to choose the experts consulted well. In this same direction, she points out the need to select the news well and apply clear inclusion criteria to avoid speculation. For this, they insist on consulting authorized expert sources, properly contextualizing the news, and fighting against misinformation.

\subsubsection{International Journalists' Network (ljnet) \\ https://ijnet.org}

Also on 6 March 2020, this project, created in 1984 in the USA, published the document entitled "Ten tips for journalists covering the new coronavirus," signed by the journalist and member of the organization Taylor Mulcahey. This decalogue mainly addresses three areas of deontological action: journalistic responsibility, respect for the truth, and nonstigmatization. In reference to responsibility, it emphasizes the need to protect the privacy of the victims, especially in photographs or images. It points out how the media must carry out responsible monitoring of the crisis based on its contextual evolution to guarantee responsible and quality journalism. It should be noted that most of the items raised refer to the principle of truth, since the document requires precision and accuracy, and diverse and reliable sources. Special care should be taken when deciding on headlines so that they do not generate misinformation or sensationalism, and racist expressions should be avoided, such as linking the virus with a country or nationality.

\subsubsection{First Draft}

https://firstdraftnews.org

As a consequence of the Covid-19 pandemic, this non-profit UK organization, formed by universities, and media and civil society entities, published on 11 March 2020 their "Tips for reporting responsibly on Covid-19 for journalists" with 13 recommendations. Linked to the principle of truth, the document strongly urges against the use of sensationalist language and recommends that special care be taken when choosing sources, as well as consulting with more than one expert to offer different points of view. The text recalls the need to avoid spreading rumors or speculation, and recommends including data, maps, and graphs that contextualize and streamline the information. Responsible communication must prevail over images or information that could generate panic and alarmism, or feed stereotypes. Furthermore, recommendations made by health authorities and official sources must be disseminated.

\subsubsection{Ethical Journalism Network} https://ethicaljournalismnetwork.org

On 18 March 2020, this coalition that works to promote ethical and responsible journalism published three documents signed by its director, Hannah Storm. They begin by explaining how to produce ethical coverage, as well as two more recommendations for maintaining the safety of journalists and avoiding contagion. The text includes deontological observations and points out the need to protect the people affected by the disease by defending their right to privacy, therefore images or names that can identify

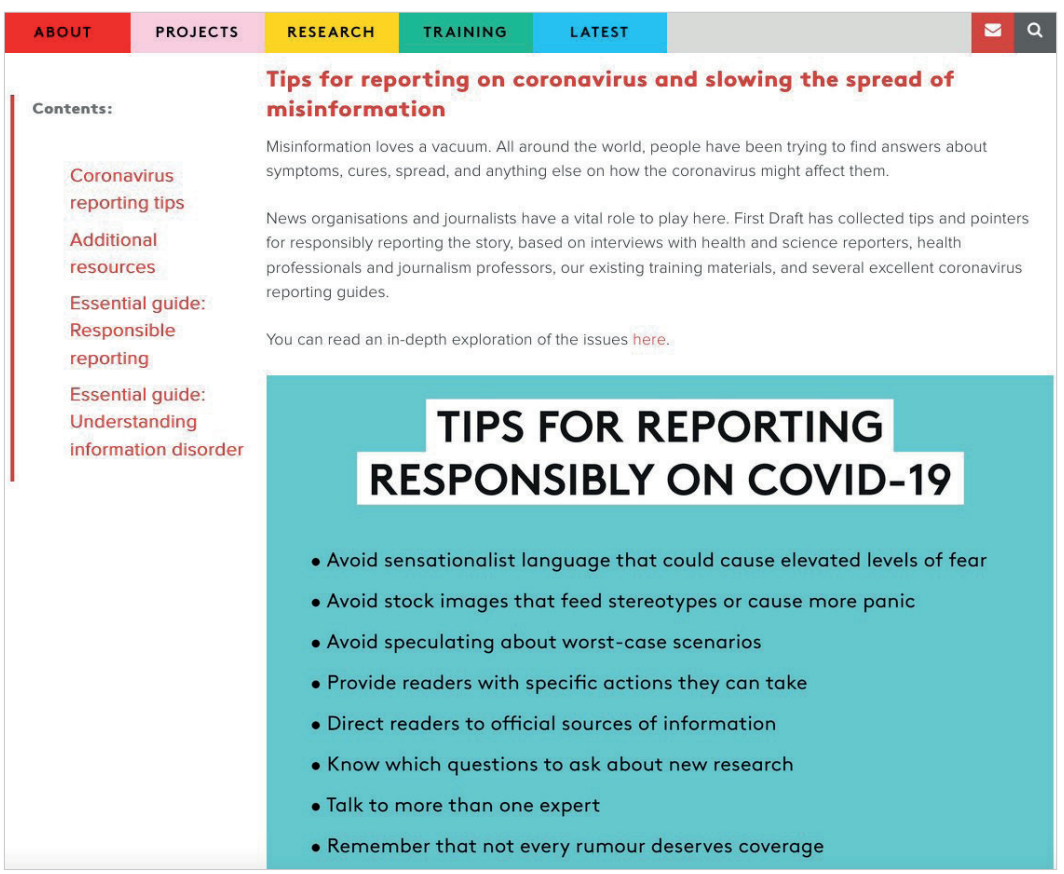

Figure 3. Guide for responsible coverage, published by First Draft 
them should not be published without their permission, appealing to the principle of responsibility. The principle of truth is also reflected in their assertion of maintaining rigor, avoiding rumors, and combatting misinformation. It agrees with other texts in the recommendation that expert opinions (scientists, doctors, etc.) be sought, while considering that their opinions may vary. Information should be contextualized to avoid sensationalism and scaremongering, for example, avoiding images of empty supermarket shelves. Finally, within the principles of justice, it advocates for the inclusion of information that avoids racial profiling and xenophobic stigmatization.

\subsubsection{Madrid Press Association} https://www.apmadrid.es

The Madrid Press Association was created in 1985 to defend freedom of information and expression and promote responsible professional practice and quality. On 30 March 2020, two weeks after the Spanish Government announced a state of alarm, they published their "Compilation of recommendations for journalists covering the pandemic." This document has six basic points, one of which refers to the protection that journalists can give to themselves to avoid contagion and others that deal with deontological aspects. The APM's recommendations are based on the principles of responsibility and truth and emphasize the need to carry out responsible communication, prioritizing humanitarian aid and public security through their appeal for reports to be responsible and balanced, and resist scaremongering. This implies reducing the use of adjectives, using photographs carefully, and explaining all the possible preventive actions that can be carried out. It demands accuracy and rigor, and for data to prevail over anecdotes. Contacting experts is recommended, but choosing wisely and ignoring unvalidated scientific findings as they should not be published. Journalists also need academic advisors to help them counter misinformation and avoid clickbait.

Table 5. Principles referenced in each text or recommendation

\begin{tabular}{|c|c|c|c|c|c|c|c|c|c|c|c|}
\hline & 01 & 02 & 03 & 04 & 05 & 06 & 07 & 08 & 09 & 10 & Total \\
\hline \multicolumn{12}{|l|}{ 1. Principle of responsibility } \\
\hline 1.1. Importance of life and the safety of people & & $x$ & & & & & & & & & 1 \\
\hline $\begin{array}{l}\text { 1.1.1. Priority of humanitarian aid } \\
\text { 1.1.2. Public safety and security }\end{array}$ & & & $x$ & & & & & & $X$ & $x$ & 3 \\
\hline 1.2. Privacy & & & & & & & & $x$ & & $x$ & 2 \\
\hline $\begin{array}{l}\text { 1.2.1. Invasion of privacy } \\
\text { 1.2.2. Child protection } \\
\text { 1.2.3. The right to one's own image } \\
\text { 1.2.4. Pain and suffering }\end{array}$ & & & & & & $x$ & & $x$ & & $X$ & 3 \\
\hline 1.3. Subjects of special social sensitivity & & & & & & & & & & $x$ & 1 \\
\hline $\begin{array}{l}\text { 1.3.1 Bad taste } \\
\text { 1.3.2. Alarmism }\end{array}$ & & & & $x$ & & & $x$ & & $X$ & $x$ & 4 \\
\hline \multicolumn{12}{|l|}{ 2. Principle of truth } \\
\hline \multicolumn{12}{|l|}{ 2.1. Informative rigor } \\
\hline $\begin{array}{l}\text { 2.1.1. Accuracy and precision } \\
2.1 .2 \text {. Conjectures, speculation, and rumors }\end{array}$ & $x$ & & $x$ & $x$ & & $x$ & $x$ & $x$ & $X$ & $x$ & 8 \\
\hline $\begin{array}{l}\text { 2.1.3. Choice, citation, and credibility of sources } \\
2.1 .4 \text {. Contextualization of the information }\end{array}$ & & $x$ & $x$ & & $x$ & $x$ & $x$ & $x$ & $x$ & $\mathrm{X}$ & 8 \\
\hline \multicolumn{12}{|l|}{ 2.2. Value neutrality } \\
\hline \multicolumn{12}{|l|}{ 2.2.1. Separation of information and opinion } \\
\hline 2.2.2. News selection and inclusion criteria & & & & & $\mathrm{X}$ & & & & & & 1 \\
\hline 2.3. Discursive procedures & & & & & & $x$ & & $x$ & & $x$ & 3 \\
\hline 2.3.1. Sensationalism and spectacularization & & & & & & & $X$ & $x$ & $x$ & $\mathrm{X}$ & 4 \\
\hline \multicolumn{12}{|l|}{ 3. Principle of justice } \\
\hline 3.2. Treatment of disadvantaged social groups & & & $x$ & & & & & & & $x$ & 2 \\
\hline 3.2.1. Racism and xenophobia & $\mathrm{X}$ & & & & & $x$ & & $\mathrm{X}$ & & & 3 \\
\hline \multicolumn{12}{|l|}{ 4. Principle of freedom } \\
\hline \multicolumn{12}{|l|}{ 4.1. External constraints and conflicts of interest } \\
\hline $\begin{array}{l}\text { 4.1.1. Control of political power } \\
\text { 4.1.2. Dependencies and commercial interests }\end{array}$ & & & & & & & & & & & \\
\hline
\end{tabular}




\subsubsection{Pan American Health Organization (PAHO) https://www.paho.org}

The $P A H O$ is an international organization specializing in public health on the American continent and serves as a regional office for the World Health Organization (WHO). On 8 April 2020, almost a month after the WHO declared the pandemic on 11 March, the PAHO published an extensive 20-page document entitled "Covid-19. Tips for reporting. Guide for journalists." This guide focuses on the ethical principles of responsibility, truth, and justice. Regarding the principle of responsibility, the guide stresses the importance of carrying out personal and community protection measures during quarantine and understanding the basic concepts of health. It values news items that promote solidarity and overcoming the disease as they guarantee responsible journalism, which is solution driven and values the work done by health professionals. The guide makes an appeal for preserving people's right to privacy, especially if they are victims, people who have contracted the virus, or those who have lost a loved one. The article promotes innovative ways to cover the news, focused on information that avoids scaremongering with its images and headlines. Linked to the principle of truth, the article advocates for facts instead of rumors, and fights against misinformation or fake news. Furthermore, it is advisable for news items to include

Table 6. Principles mentioned in each text or recommendation

\begin{tabular}{|c|c|}
\hline \multicolumn{2}{|c|}{ Fundamental ethical principles examined } \\
\hline 1. Principle of responsibility & $\begin{array}{l}\text { 01. Information is a public good, and journalism is a profession of public service. In crisis situations, one } \\
\text { must act even more responsibly, and giving information is synonymous with giving peace of mind. Priori- } \\
\text { tize quiet journalism and, even when the situation improves, coverage should not be abandoned. }\end{array}$ \\
\hline $\begin{array}{l}\text { 1.1. Importance of life and the } \\
\text { safety of people }\end{array}$ & $\begin{array}{l}\text { 02. Promote personal and community protection measures in coverage. } \\
\text { 03. Provide suggestions on activities to do during isolation. } \\
\text { 04. Disseminate actions that promote solidarity. } \\
\text { 05. Help citizens understand that social distancing measures may be prolonged. } \\
\text { 06. Find innovative ways to conduct interviews avoiding direct contact with victims or quarantined. } \\
\text { 07. Report on medical progress. }\end{array}$ \\
\hline $\begin{array}{l}\text { 1.1.1. Priority of humani- } \\
\text { tarian aid }\end{array}$ & $\begin{array}{l}\text { 08. Reflect the work that health personnel do. } \\
\text { 09. Report success stories of recovering from the disease. } \\
\text { 10. Explain in a simple way public health concepts that are difficult for the general public to understand. } \\
\text { 11. Provide stories to give visibility to the most socially vulnerable groups. }\end{array}$ \\
\hline $\begin{array}{l}\text { 1.1.2. Public safety and } \\
\text { security }\end{array}$ & $\begin{array}{l}\text { 12. Emergency and relief tasks take priority over information. } \\
\text { 13. Disseminate recommendations from health authorities and measures taken to contain or mitigate the } \\
\text { spread of the disease. Promote content on basic prevention and protection measures for different popula- } \\
\text { tion groups, especially the most vulnerable and at risk. } \\
\text { 14. Avoid congregating outside of health centers and residences, and do not enter restricted areas. }\end{array}$ \\
\hline 1.2. Privacy & $\begin{array}{l}\text { 15. The people we report on have the right to privacy and confidentiality. This right will be respected, } \\
\text { especially in the case of patients. } \\
\text { 16. The suffering of the interviewees should be avoided. Let the victims decide where to be interviewed. } \\
\text { It must be certain that the victim understands the purpose of the interview and gives consent, and is } \\
\text { informed about where it will be published and with what intention. }\end{array}$ \\
\hline 1.2.1. Invasion of privacy & $\begin{array}{l}\text { 17. If it is necessary to provide data on victims, which will be based on proven and accurate information. } \\
\text { Do not venture into the victim's relationships until they are official facts. } \\
\text { 18. Be empathetic, patient, and flexible with victims: interviewing a person who has suffered a trauma } \\
\text { requires time. }\end{array}$ \\
\hline $\begin{array}{l}\text { 1.2.3. The right to one's } \\
\text { own images }\end{array}$ & $\begin{array}{l}\text { 19. No names, images, or any material will be identified without the permission of the person concerned. } \\
\text { Revealing the identity or providing detailed personal information of patients or affected without their } \\
\text { consent will be avoided. } \\
\text { 20. Having visual information is important, but it must be handled responsibly. }\end{array}$ \\
\hline 1.2.4. Pain and suffering & $\begin{array}{l}\text { 21. In the informative treatment of matters that involve elements of pain and distress, the journalist will } \\
\text { avoid gratuitous interference and unnecessary speculation about feelings and circumstances. } \\
\text { 22. Restrictions on intrusions on privacy should be observed with special care when dealing with indivi- } \\
\text { duals in hospitals or nursing homes. } \\
\text { 23. Give due consideration to people who have lost a family member. }\end{array}$ \\
\hline $\begin{array}{l}\text { 1.3. Subjects of special social } \\
\text { sensitivity }\end{array}$ & $\begin{array}{l}\text { 24. When it comes to defending democratic values, no one should be neutral. } \\
25 . \text { It should be reported with passion, not fear. }\end{array}$ \\
\hline 1.3.4. Alarmism & $\begin{array}{l}\text { 26. Avoid the use of photos or images that can create stigma or fear. Images must be chosen with care. } \\
\text { 27. Avoid giving a voice to those who from ignorance or misinformation bring confusion, anxiety, and fear. } \\
\text { 28. Be aware of the effects that the publication of certain news can have. Avoid fueling fear and stigma- } \\
\text { tization. The information should contribute to dismantling myths about the disease and to disseminate } \\
\text { preventive actions. } \\
\text { 29. Limit the number of qualifying adjectives about the disease (e.g., fatal conditions) } \\
\text { 30. Be cautious about broadcasting images of people wearing masks. }\end{array}$ \\
\hline 2. Principle of truth & $\begin{array}{l}\text { 31. A journalist's first ethical commitment is to the truth. The primary duty of the journalist includes respecting } \\
\text { factual truths and the public's right to know them. The transmission of information must be done truthfully. }\end{array}$ \\
\hline 2.1. Informative rigor & $\begin{array}{l}\text { 32. Convey true facts and information about the disease, not fears. } \\
\text { 33. To inform, one must know the basic foundations of epidemiology and which questions to ask. } \\
\text { 34. Reporting should always continue, even in uncertainty, but based on what is known. }\end{array}$ \\
\hline
\end{tabular}




\begin{tabular}{|c|c|}
\hline $\begin{array}{l}\text { 2.1.1. Accuracy and } \\
\text { precision }\end{array}$ & $\begin{array}{l}\text { 35. The commitment to accurate and precise information must be extreme in crisis and emergency situa- } \\
\text { tions. } \\
\text { 36. Help make medical information or jargon understandable to the public. } \\
\text { 37. Provide truthful information about where to seek help or medical care. } \\
\text { 38. Factual stories are more accurate than anecdotal stories. } \\
\text { 39. Not all figures are accurate. }\end{array}$ \\
\hline $\begin{array}{l}\text { 2.1.2. Conjectures, specu- } \\
\text { lation, and rumors }\end{array}$ & $\begin{array}{l}\text { 40. No rumors or speculations deserve coverage. There is a lot of misinformation in outbreak and crisis } \\
\text { situations that the journalist must combat and not spread. Damage generated by information without } \\
\text { sufficient basis must be avoided. } \\
\text { 41. If unconfirmed data is disseminated, it should not be included in the title. } \\
\text { 42. Do not propagate false or unscientific theories. Be careful in citing findings published in scientific } \\
\text { articles if they have not been published or are in the evaluation process. }\end{array}$ \\
\hline $\begin{array}{l}\text { 2.1.3. Choice, citation, } \\
\text { and credibility of sources }\end{array}$ & $\begin{array}{l}\text { 43. The notion of urgency or immediacy in the dissemination of information shall not prevail over the } \\
\text { verification of facts and sources. } \\
\text { 44. Use reliable, truthful, scientific, and proven sources. It is important to provide a voice to researchers, } \\
\text { healthcare providers, academics, and specialists on the front line, but they must be carefully selected to } \\
\text { distinguish those who know with certainty from those who believe that what they say is true but have not } \\
\text { proven it. Give a voice to nurses because journalism tends to promote the vision of men when they have a } \\
\text { lot of access to information. } \\
\text { 45. Provide expert sources to help the journalist measure the journalistic relevance of new medical } \\
\text { findings to prevent misinformation from spreading. Beware of sources that think they are experts but are } \\
\text { not. } \\
\text { 46. Provide the public with resources and accurate information from authoritative and credible sources. } \\
\text { 47. Check stories that emerge on social networks before posting them. }\end{array}$ \\
\hline $\begin{array}{l}\text { 2.1.4. Contextualization } \\
\text { of the information }\end{array}$ & $\begin{array}{l}\text { 48. Go beyond the numbers of cases and deaths and contribute to setting the context and giving advice } \\
\text { for health. } \\
\text { 49. Include the source of the data and the context in maps and graphs }\end{array}$ \\
\hline 2.2. Value neutrality & $\begin{array}{l}\text { 50. Journalists must investigate and publish relevant information honestly, comment fairly, and generate } \\
\text { criticism honestly, including in emergency situations. }\end{array}$ \\
\hline $\begin{array}{l}\text { 2.2.2. News selection and } \\
\text { inclusion criteria }\end{array}$ & $\begin{array}{l}\text { 51. Do not publish facts where the origin of the information is unknown, without falsifying data or omit- } \\
\text { ting information. }\end{array}$ \\
\hline 2.3. Discursive procedures & $\begin{array}{l}\text { 52. Include visual material (infographics, graphics, etc.) as it allows complex issues to be explained better. } \\
\text { 53. Be careful when displaying maps about the distribution of the pandemic. The necessary context and } \\
\text { sources should always be given. }\end{array}$ \\
\hline $\begin{array}{l}\text { 2.3.1. Sensationalism and } \\
\text { spectacularization }\end{array}$ & $\begin{array}{l}\text { 54. Be realistic when reporting. Do not be alarmist or sensationalist, or dramatize the information. } \\
\text { 55. Avoid headlines or the use of images to attract an audience. Information cannot be mediated by the } \\
\text { demands to increase the number of readers. } \\
\text { 56. Avoid the spectacularization of information. Avoid set phrases and adjectives that dramatize. Avoid } \\
\text { the use of zoom, plans, or resources that spectacularize, or images that generate panic or anxiety. Do not } \\
\text { confuse the conflictive or spectacular with what is important from an informational point of view. } \\
\text { 57. Corroborate and edit images of citizens found online. }\end{array}$ \\
\hline $\begin{array}{l}\text { 2.4. Misleading procedures in } \\
\text { obtaining information }\end{array}$ & $\begin{array}{l}\text { 58. Information, data, or images will always be obtained by legal, lawful, and ethical methods. The ends do } \\
\text { not always justify the means. }\end{array}$ \\
\hline \multicolumn{2}{|l|}{ 3. Principle of justice } \\
\hline \multicolumn{2}{|l|}{ 3.1. Impartiality } \\
\hline $\begin{array}{l}\text { 3.1.1. Inclusion of diffe- } \\
\text { rent points of view }\end{array}$ & $\begin{array}{l}\text { 59. Do not put blind faith in any source. Consult as many sources as possible. It should be considered that } \\
\text { scientific criteria change frequently, so it is advisable to speak with more than one expert. }\end{array}$ \\
\hline $\begin{array}{l}\text { 3.2. Treatment of disadvantaged } \\
\text { social groups }\end{array}$ & $\begin{array}{l}\text { 60. Do not amplify the stigmatization of people affected by the disease. It is advisable to speak of "the } \\
\text { people who have Covid-19" instead of "the cases" or "the victims." It is better to speak of people who "ac- } \\
\text { quire" or "contract" the virus, rather than people who "spread the virus" or "infect others." } \\
\text { 61. Be very careful in the use of words because they can have negative connotations that feed stigmatiza- } \\
\text { tion towards groups. } \\
\text { 62. Do not focus informational attention only on the groups most at risk. }\end{array}$ \\
\hline $\begin{array}{l}\text { 3.2.1. Racism and xe- } \\
\text { nophobia }\end{array}$ & $\begin{array}{l}\text { 63. Avoid racial profiling when discussing the disease. Do not spread incorrect names about the virus } \\
\text { focused on countries or cities. Avoid focusing on "patient zero" or on the country or countries of origin of } \\
\text { the disease. Doing so reinforces stigmatization. }\end{array}$ \\
\hline \multicolumn{2}{|l|}{ 4. Principle of freedom } \\
\hline $\begin{array}{l}\text { 4.1. External constraints and } \\
\text { conflicts of interest }\end{array}$ & $\begin{array}{l}\text { 64. The journalist shall refrain from acting as an assistant to the police or other security forces. } \\
65 . \text { It is the journalist's responsibility to ensure compliance by public administrations with their obligation } \\
\text { of transparency, also in situations of crisis or states of alarm. }\end{array}$ \\
\hline $\begin{array}{l}\text { 4.1.1. Control of political } \\
\text { power }\end{array}$ & $\begin{array}{l}\text { 66. The regulations necessary to control the pandemic are no excuse for limiting the right to free informa- } \\
\text { tion. }\end{array}$ \\
\hline
\end{tabular}


basic notions of epidemiology to verify data and make specialized language more understandable. The guide recommends reporting at any and all times, but with the necessary context: infographics and graphic materials, as well as reliable, truthful, and verified sources that inform and reflect on the situation, along with authorized messages from health organizations. The recommendations end by mentioning the principle of justice, asking journalists to avoid stigmatizing those affected by the disease, focusing on patient zero, or linking the disease with a single group or nationality.

\subsection{Principles and recommendations: comparative perspective}

A comparative analysis of the ten selected texts allows us to verify the extent to which the principles of truth, freedom, responsibility, and justice are present in the published recommendations. The first thing to note from the analysis is

Table 7. Proposed recommendations for ethical and responsible coverage

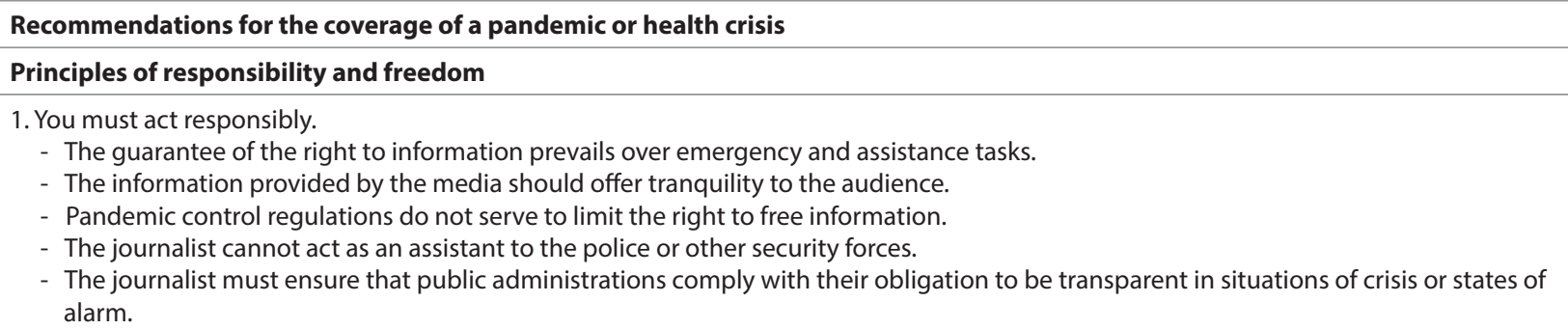

2. It is necessary to promote personal and community protection measures in coverage.

- It is recommended to look for innovative ways to conduct interviews to avoid direct contact with victims or quarantined persons.

We must avoid congregating outside health centers and residences, and do not enter restricted areas.

3. The journalist must explain public health concepts in a way that is understandable to the general public.

- It is necessary to make citizens understand that social distancing measures may be prolonged.

It is recommended to disclose the recommendations of the health authorities and the measures taken to contain or mitigate the spread of the disease.

Truthful information on how to seek help or medical attention must be published.

\section{Principle of truth}

4. It is necessary to respect the truth of the facts and the right of the public to know it.

- In crisis and emergency situations, it is necessary to preserve the commitment to accurate and precise information

The number of infections and deaths must be transcended and contribute to putting the information into context.

5. It is desirable to consult as many reliable, scientific, and proven sources as possible, but they must be carefully selected to distinguish what is known with certainty from what is not proven.

- Blindly trusting any source is discouraged.

- It should be considered that scientific criteria change frequently and that in the scientific, academic, and health fields there are also different views.

It is recommended to give a voice to health personnel of both genders to counteract the large number of male sources used.

6. You need to know the basics of epidemiology to gauge the relevance of new medical findings and avoid misinformation and fake news.

- It is recommended to publish information with an adequate balance between data and anecdotal stories.

It is advisable to publish visual material (infographics, graphics) as they allow you to better explain complex issues.

7. It is not recommended to publish information whose origin is unknown.

- No rumors or speculation deserve coverage, and the journalist must combat misinformation in outbreak and crisis situations.

- It is necessary to avoid the publication of false or unscientific theories.

The damage generated by information without a sufficient basis must be avoided.

Unconfirmed data cannot appear in the title of the information.

8. Stories or images posted on social media should be verified and edited before posting.

9. In emergency situations, it is necessary to honestly investigate and publish relevant information, comment fairly, and generate criticism.

10. You must be realistic when reporting and avoid being alarmist, sensationalist, or dramatizing the information in order to attract an audience.

- It is advised to avoid set phrases and adjectives that are more dramatic.

- It is not recommended to use zooms, plans, or resources that spectacularize, or images that generate panic or anxiety.

Conflictive or spectacular reporting should not be confused with what is important from an informational point of view.

11. It is essential to obtain information, data, or images by legal, lawful, and ethical methods.

\section{Principle of justice}

12. It is recommended not to amplify the stigmatization of people affected by the disease.

- It is necessary to be careful with the use of words that have negative connotations and fuel stigmatization towards groups.

- It is advisable to use "people who have Covid-19" instead of "the cases" or "the victims."

It is considered preferable to speak of people who "acquire" or "contract" the virus, instead of people who "spread the virus" or "infect others."

13. Informational attention must not only focus on the highest risk groups, and it is recommended to report on stories of overcoming the disease. It is necessary to give visibility to the most socially vulnerable groups.

14. Talking about racial profiling related to Covid-19 should be avoided

- It is recommended not to spread incorrect names about the virus focused on countries or cities.

- The information should not focus on the "patient zero" or on the country or countries of origin of the disease, as this may reinforce stigmatization.

When maps on the distribution of the pandemic are shown, it is necessary to provide context and indicate the sources consulted. 
that, in some cases, the documents reviewed address the principles identified quite broadly, but in most cases, they explore a specific aspect (Table 5). The results suggest that informative rigor is one of the most common values explored, with 8 of the 11 analyzed texts mentioning this, as well as precision and accuracy when reporting, and the need to avoid rumors and speculation.

The health risks that the publication of inaccurate data or misinformation may imply may explain the strong presence of recommendations linked to the principle of truth (Brennen et al., 2020; Pérez-Dasilva et al., 2020; Pulido et al., 2020; Sánchez-Duarte; Magallón-Rosa, 2020), as well as the novelty of the crisis. Along these lines, eight of the documents stressed the importance of choosing sources well and providing context, and four documents explicitly recommend avoiding sensationalism. Responsibility is the second most reiterated principle, specified in the need to preserve life and safety, respect privacy, and avoid alarmism. Likewise, responsible information is required, taking into account potential suffering and fear, and working to dispel these feelings. The principle of justice, which implies the nonstigmatization of socially disadvantaged groups (in this case those who have contracted the virus), only appears on two occasions, and the need to avoid racism is mentioned only three times, with particular emphasis in the document by the Asian American Journalists Association. Finally, there is no mention of the principle of freedom in these documents, unlike within the three transnational reference codes also analyzed.

Based on a comparative analysis of the ten texts that specifically mention recommendations for coverage of the Covid-19 crisis and the three general codes of ethics, a total of 66 specific indications for the media and journalists can be extracted (Table 6) regarding how to carry out ethical and responsible coverage in the current crisis situation.

Taking the indications of the reference codes at a transnational level and the guides proposed by the ten organizations analyzed as a starting point, a proposal is presented that synthesizes the main recommendations from the analyzed codes in 14 points, based on the classification of deontological principles elaborated by Alsius (2010). Note that, in the presentation of the recommendations (Table 7), points 1-3 correspond to principles related to the responsibility of the media and freedom, points 4-11 correspond to the truth principle, and points 12-14 correspond to the principle of justice. This proposal collates, orders, and synthesizes the main recommendations that appear in the analyzed codes.

\section{Conclusions}

In a context marked by economic difficulties, the precariousness of journalistic practice, and a media credibility crisis (Fengler et al., 2015; Hanitzsch et al., 2018), efforts to align media professionals towards self-regulation, one of the basic components of accountability, have fundamental value. Codes of ethics are self-regulatory tools with a long history and the ability to establish key values and guidelines for professional behavior (Alsius, 2010; Bertrand, 2018; Wilkins; Christians, 2020). Crisis situations, such as the current Covid-19 pandemic, are marked by uncertainty, the rapid spread of information, and the growth of sensationalism and disinformation, and within them, self-regulation documents acquire fundamental value. This paper presents the recommendations published by various platforms and independent organizations since the beginning of the current crisis with the aim of helping information professionals carry out responsible coverage. These recommendations complement and extend preexisting standards in key transnational codes, promulgated by reference institutions such as Unesco, the International Federation of Journalists, and the Council of Europe.

In the current context, it is essential for journalists to receive clear guidelines describing how to deal with both current and future coverage of Covid-19, or other health crises. It is for this reason that the objective of the synthesized code recommendations (Table 7 ) is to guarantee responsible coverage, but not in a theoretical way, but rather practically, since the purpose is to reach information professionals and guide them in their work to develop ethical coverage. From the media's perspective, the coverage of the pandemic is an opportunity to regain their audience's trust and respond to the need for reliable and responsible journalism.

As a self-regulatory tool, the current proposal addresses many doubts within the media sector and focuses journalistic work on professional excellence. Within the educational environment, these recommendations form part of the range of resources available to communication faculties to train students on how to carry out information tasks responsibly in times of crisis (Auman; Stos; Burch, 2020). For this reason, this proposal is a useful tool for the training of new journalists.

The results of this work add to the set of investigations that delve into the ethical behavior of both the national and international media during the Covid-19 crisis. Media coverage from multiple platforms (written press, online press, radio, television, and social networks) can be analyzed alongside the deontological recommendations presented herein to determine the quality of published journalistic information. 
This work has focused on documents published within the first few months of the pandemic (February-April 2020), representing a potential limitation to the investigation. Future studies should monitor the emergence of new recommendations that complement and expand those analyzed here. Knowledge obtained through future research can contribute decisively to professional and academic reflection and decision-making.

\section{References}

Alexander, Jeffrey C.; Breese, Elisabeth-Butler; Luengo, María (eds.) (2016). The crisis of journalism reconsidered. New York: Cambridge University Press. ISBN: 9781107085251

Almiron, Núria (2009). "Grupos privados propietarios de medios de comunicación en España: principales datos estructurales y financieros". Communication \& society, v. 22, n. 1, pp. 243-263.

https://hdl.handle.net/10171/8622

Alsius, Salvador (ed.) (2010). The ethical values of journalists: field research among media professionals in Catalonia. Barcelona: Lexikon. ISBN: 9788439383468

Andreu-Sánchez, Celia; Martín-Pascual, Miguel-Ángel (2020). "Fake images of the SARS-CoV-2 coronavirus in the communication of information at the beginning of the first Covid-19 pandemic". El profesional de la información, v. 29, n. 3, e290309. https://doi.org/10.3145/epi.2020.may.09

Auman, Ann; Stos, Susan; Burch, Elizabeth (2020). "Ethics without borders in a digital age". Journalism \& mass communication educator, v. 75, n. 1, pp. 9-15.

https://doi.org/10.1177/1077695820901941

Aznar, Hugo (2005). Ética de la comunicación y nuevos retos sociales: códigos y recomendaciones para los medios. Barcelona: Paidós. ISBN 8449316855

Bardoel, Jo L.; D’Haenens, Lee (2004). “Media responsibility and accountability: New conceptualizations and practices". Communications, v. 29, n. 1, pp. 5- 25.

https://doi.org/10.1515/comm.2004.007

Bertrand, Claude-Jean (ed.) (2018). Media ethics and accountability systems. New York: Routledge. ISBN: 1560004207

Biernacki, Patrick; Waldorf, Dan (1981). "Snowball sampling: Problems and techniques of chain referral sampling". Sociological methods \& research, v. 10, n. 2, pp. 141-163.

https://doi.org/10.1177/004912418101000205

Brennen, J. Scott; Simon, Felix; Howard, Philip N.; Nielsen, Rasmus-Kleis (2020). Types, sources, and claims of Covid-19 misinformation. Oxford: Reuters Institute for the Study of Journalism.

https://reutersinstitute.politics.ox.ac.uk/types-sources-and-claims-covid-19-misinformation

Brickman-Bhutta, Christine (2012). "Not by the book: Facebook as a sampling frame". Sociological methods \& research, v. 41, n. 1 , pp. 57-88.

https://doi.org/10.1177/0049124112440795

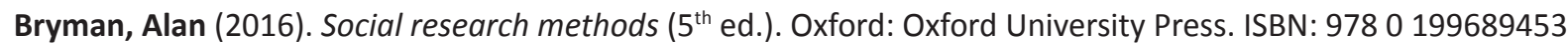

Casero-Ripollés, Andreu (2010). "Prensa en internet: nuevos modelos de negocio en el escenario de la convergencia”. El profesional de la información, v. 19, n. 6, pp. 595-601.

https://doi.org/10.3145/epi.2010.nov05

Casero-Ripollés, Andreu (2020). "Impact of Covid-19 on the media system. Communicative and democratic consequences of news consumption during the outbreak". El profesional de la información, v. 29, n. 2, e290223.

https://doi.org/10.3145/epi.2020.mar.23

Christians, Clifford; Nordenstreng, Kaarle (2004). "Social responsibility worldwide". Journal of mass media ethics, v. 19, n. 1, pp. 3-28.

https://doi.org/10.1207/s15327728jmme1901_2

Cooper, Tom (1990). “Comparative international media ethics". Journal of mass media ethics, v. 5, n. 1, pp. 3-14.

https://doi.org/10.1207/s15327728jmme0501_1

Duncan, Sallyanne (2019). "The ethics". In: Healey, Jo. Trauma reporting: A journalist's guide to covering sensitive stories. New York: Routledge, pp. 186-198. ISBN: 9781138482098

Evers, Huub (2012). "The news ombudsman: Lightning rod or watchdog?". Central European journal of communication, v. 5, n. 2, pp. 224-242.

https://cejc.ptks.pl/Volume-5-No-2-9-Fall-2012/The-news-ombudsman-Lightning-rod-or-watchdog 
Fengler, Susanne (2019). “Accountability in journalism”. In: Vos, Tim; Hanusch, Folker (eds.). The international encyclopedia of journalism studies. Hoboken, New Jersey: Wiley-Blackwell, pp. 1-8. ISBN: 9781118841679 https://doi.org/10.1002/9781118841570.iejs0078

Fengler, Susanne; Eberwein, Tobias; Alsius, Salvador; Baisnée, Olivier; Bichler, Klaus; Dobek-Ostrowska, Boguslawa; Evers, Huub; Glowacki, Michal; Groenhart, Harmen; Harro-Loit, Halliki; Heikkilä, Heikki; Jempson, Mike; Karmasin, Matthias; Lauk, Epp; Lönnendonker, Julia; Mauri, Marcel; Mazzoleni, Gianpietro; Pies, Judith; Porlezza, Colin; Powell, Wayne; Radu, Raluca; Rodríguez-Martínez, Ruth; Russ-Mohl, Stephan; Schneider-Mombaur, Laura; Splendore, Sergio; Väliverronen, Jari; Vera-Zambrano, Sandra (2015). "How effective is media self-regulation? Results from a comparative survey of European journalists". European journal of communication, v. 30, n. 3, pp. 249-266. https://doi.org/10.1177/0267323114561009

Fengler, Susanne; Eberwein, Tobias; Mazzoleni, Gianpetro; Porlezza, Colin; Russ-Mohl, Stephan (2014). Journalists and media accountability. An international study of news people in the digital age. New York: Peter Lang. ISBN: 9781433122811

Figueras-Maz, Mònica; Mauri-Ríos, Marcel; Alsius, Salvador; Salgado-De-Dios, Francesc (2012). "La precariedad te hace dócil: Problemas que afectan a la profesión periodística". El profesional de la información, v. 21, n. 1, pp. 70-75. https://doi.org/10.3145/epi.2012.ene.09

González, Francisca-Greene; Lecaros, María-José (2020). "The concept of self-regulation and the ethics council of the media federation of Chile". Journal of information, communication and ethics in society.

https://doi.org/10.1108/JICES-11-2019-0127

Goodman, Leo A. (1961). "Snowball sampling". Annals of mathematical statistics, v. 32, n. 1, pp. 148-170. https://doi.org/10.1214/aoms/1177705148

Hanitzsch, Thomas; Van-Dalen, Arjen; Steindl, Nina (2018). "Caught in the nexus: A comparative and longitudinal analysis of public trust in the press". The international journal of press/politics, v. 23, n. 1, pp. 3-23.

https://doi.org/10.1177/1940161217740695

Herrscher, Roberto (2002). "A universal code of journalism ethics: Problems, limitations, and proposals". Journal of mass media ethics, v. 17, n. 4, pp. 277-289.

https://doi.org/10.1207/S15327728JMME1704_03

Himelboim, Itai; Limor, Yehiel (2008). "Media perception of freedom of the press: A comparative international analysis of 242 codes of ethics". Journalism, v. 9, n. 3, pp. 235-265.

https://doi.org/10.1177/1464884907089007

Maciá-Barber, Carlos (2020). “Covid-19 en portada: radiografía ética de la cobertura fotográfica de la pandemia en España". Revista española de comunicación en salud, Suplemento 1, pp. 42-58.

https://doi.org/10.20318/recs.2020.5435

Maier, Scott R. (2014). “Foreword”. In: Fengler, Susanne; Eberwein, Tobias; Mazzoleni, Gianpetro; Porlezza, Colin; RussMohl, Stephan (2014). Journalists and media accountability. An international study of news people in the digital age. New York: Peter Lang, pp. 1-6. ISBN: 9781433122811

Masip, Pere; Aran-Ramspott, Sue; Ruiz-Caballero, Carlos; Suau, Jaume; Almenar, Ester; Puertas-Graell, David (2020). "Consumo informativo y cobertura mediática durante el confinamiento por el Covid-19: sobreinformación, sesgo ideológico y sensacionalismo". El profesional de la información, v. 29, n. 3, e290312.

https://doi.org/10.3145/epi.2020.may.12

Mauri-Ríos, Marcel; Marcos-García, Silvia; Zuberogoitia-Espilla, Aitor (2020). "Analysis of professional perceptions relating to the effectiveness of codes of ethics for journalists in Spain". Journal of information, communication and ethics in society, v. 18, n. 4, pp. 511-528.

https://doi.org/10.1108/JICES-11-2019-0123

OMS (2020). Rolling updates on coronavirus disease (Covid-19), February 2.

https://www.who.int/docs/default-source/coronaviruse/situation-reports/20200202-sitrep-13-ncov-v3.pdf

Pérez-Dasilva, Jesús-Ángel; Meso-Ayerdi, Koldobika; Mendiguren-Galdospín, Terese (2020). "Fake news y coronavirus: detección de los principales actores y tendencias a través del análisis de las conversaciones en Twitter". El profesional de la información, v. 29, n. 3, e290308.

https://doi.org/10.3145/epi.2020.may.08

Pritchard, David-Hemmings (ed.) (2000). Holding the media accountable: Citizens, ethics, and the law. Bloomington: Indiana University Press. ISBN: 9780253213570 
Pulido, Cristina M.; Villarejo-Carballido, Beatriz; Redondo-Sama, Gisela; Gómez, Aitor (2020). “Covid-19 infodemic: More retweets for science-based information on coronavirus than for false information". International sociology, v. 35 , n. 4, pp. 377-392.

https://doi.org/10.1177/0268580920914755

Ramon-Vegas, Xavier; Mauri-Ríos, Marcel; Alcalá-Anguiano, Fabiola (2016). "Transparencia informativa, autorregulación y participación del público: Mural.com, Rue89.com y TexasTribune.org". Comunicación y sociedad, n. 25, pp. 101125.

https://doi.org/10.32870/cys.v0i25.4423

Ramon-Vegas, Xavier; Mauri-Ríos, Marcel; Díaz-Campo, Jesús (2020). “Instrumentos de rendición de cuentas impulsados por los medios de comunicación: percepción de los periodistas y ciudadanos españoles". Revista de comunicación, v. 19 , n. 1, pp. 221-241.

https://doi.org/10.26441/RC19.1-2020-A13

Real-Rodríguez, Elena (2018). “La profesión periodística ante sus retos éticos: Autorregulación profesional y comunicativa frente a regulación. La situación en España". Estudios sobre el mensaje periodístico, v. 24, n. 1, pp. 341-360. https://doi.org/10.5209/ESMP.59954

Reig, Ramón (2015). Crisis del sistema, crisis del periodismo. Barcelona: Gedisa. ISBN: 9788497849111

Ricketson, Matthew; Dodd, Andrew; Zion, Lawire; Winarnita, Monika (2020). ''Like being shot in the face' or 'I'm glad I'm out': Journalists' experiences of job loss in the Australian media industry 2012-2014". Journalism studies, v. 21, n. 1, pp. 54-71.

https://doi.org/10.1080/1461670X.2019.1627899

Ruiz-Olabuénaga, José-Ignacio; Aristegui, Iratxe; Melgosa, Leire (1998). Cómo elaborar un proyecto de investigación social. Bilbao: Universidad de Deusto. ISBN: 9788474855470

Salaverría, Ramón; Buslón, Nataly; López-Pan, Fernando; León, Bienvenido; López-Goñi, Ignacio; Erviti, María-Carmen (2020). "Desinformación en tiempos de pandemia: tipología de los bulos sobre la Covid-19". El profesional de la información, v. 29, n. 3, e290315.

https://doi.org/10.3145/epi.2020.may.15

Sánchez-Duarte, José-Manuel; Magallón-Rosa, Raúl (2020). “Infodemia y Covid-19. Evolución y viralización de informaciones falsas en España”. Revista española de comunicación en salud, n. S1, pp. 31-41.

https://doi.org/10.20318/recs.2020.5417

Sherwood, Merryn; O’Donnell, Penny (2018). “Once a journalist, always a journalist? Industry restructure, job loss and professional identity". Journalism studies, v. 19, n. 7, pp. 1021-1038.

https://doi.org/10.1080/1461670X.2016.1249007

Wilkins, Lee; Christians, Clifford (eds.) (2020). The routledge handbook of mass media ethics. New York: Routledge. ISBN: 9781138681323

\section{$\cdots$ छाRIS COMUNICACIÓN \\ https://www.rediris.es/list/info/comunicacion.htm/}

Comunicación es una lista de distribución en castellano para debatir y estar al día sobre teoría de la comunicación, comunicación política, comunicación industrial, relaciones públicas, comunicación audiovisual y multimedia, radio y televisión, cinematografía, periodismo, periodismo de datos, divulgación de la ciencia, medios y cibermedios, redes sociales... y todos los aspectos relacionados con la COMUNICACIÓN.

Empezó a funcionar en enero de 2017 y está alojada en el servicio de listas de RedIRIS, desde donde es posible consultar sus archivos:

https://listserv.rediris.es/cgi-bin/wa?A0=COMUNICACION

La lista cuenta con 2 moderadores que permanentemente filtran los mensajes para evitar spam, mensajes inapropiados, anuncios, mensajes repetidos, etc.:

Isabel Olea (EPI, León)

Tomàs Baiget (EPI, Barcelona)

Puedes suscribirte a Comunicación en:

https://listserv.rediris.es/cgi-bin/wa?SUBED1=COMUNICACION\&A=1 